\title{
Different Weed Management Practices and Their Effect on Soil Micro Flora in Spring Season Sweet Corn (Zea mays L. saccharata) in Tarai Region of Uttarakhand, India
}

\author{
Prithwiraj Dey $^{1 *}$, Tej Pratap ${ }^{1}$, Sudershan Mishra ${ }^{2}$, Sanjib Kumar Sahoo ${ }^{3}$ and \\ Saipayan Ghosh ${ }^{4}$ \\ ${ }^{1}$ Department of Agronomy, ${ }^{2}$ Department of Plant Physiology, ${ }^{3}$ Department of Soil Science, \\ ${ }^{4}$ Department of Molecular Biology and Genetic Engineering, G.B. Pant University of \\ Agriculture \& Technology, Pantnagar, India
}

*Corresponding author

\section{A B S T R A C T}

\begin{tabular}{|c|}
\hline Keywords \\
\hline $\begin{array}{l}\text { Atrazine, Dehydrogenase, } \\
\text { Resilience, Sweet corn, } \\
\text { Tembotrione, } \\
\text { Halosulfuron-methyl }\end{array}$ \\
\hline Article Info \\
\hline $\begin{array}{l}\text { Accepted: } \\
20 \text { August } 2018 \\
\text { Available Online: } \\
\text { 10 September } 2018\end{array}$ \\
\hline
\end{tabular}

A study was conducted in the spring season of 2017 in sweet corn crop to evaluate different weed management practices with different combinations of cultural, manual methods with some recommended and new generation herbicides to find the best management practice with lowest impact upon soil health. Effectiveness of weed control measures were evaluated on the basis of total weed dry matter accumulation and weed control efficiency. Pre-emergence application of atrazine $1000 \mathrm{~g} / \mathrm{ha}$ which is a generally practiced weed management measure was found to have detrimental effects upon soil micro flora as indicated from the decline in soil dehydrogenase activity. The study also indicated about the time that a healthy soil needs to recover from the damage caused to the soil micro flora by application of different chemicals.

\section{Introduction}

Maize is one of the potential cereal crops grown in India. Due to its versatility in use and huge production potential it is referred as the 'Queen of Cereals'. Sweet corn (Zea mays L. var. saccharata) is a special kind of maize having at least $16 \%$ sugar in its kernel. It is a crop grown for fresh green cobs for human consumption and also used as raw or processed material for the food industry throughout the world. It's taste and nutritional value have made it a valued crop in all countries and the scope of corn production is constantly increasing (Olabode and Sangodele, 2015). Among the several factors most critical for the low yield of maize appears to be the weeds, competing with the 
crop for nutrients, water, sunlight and space. Maize is highly suffered by the weeds due to wider spacing and slow initial growth of maize which favours the growth of weeds. Yield losses due to weeds in maize vary from 28 to $93 \%$, depending on the type of weed flora and intensity and duration of crop-weed competition (Sharma and Thakur, 1998). Use of herbicides for managing the weeds is not necessarily an economically and ecologically fitting option every time as there are limitations and advantages of every weed control method, therefore integrated weed management is a good option for a sustainable production system (Ehsas et al., 2016). Also for sustainable production systems, soil health is of prime importance. This study aims at narrowing down suitable the weed management practices along with evaluating their impact upon soil health in spring sweet corn.

\section{Materials and Methods}

The experiment was conducted during spring season of 2017 in N. E Borlaug Crop Research Centre of G.B. Pant University of Agriculture \& Technology, Pantnagar, Uttarakhand, India $\left(29^{\circ} \mathrm{N}, 79.3^{\circ} \mathrm{E}\right)$. The soil on the experimental site was sandy loam, neutral in $\mathrm{pH}$ (7.3) with high organic carbon $(0.79 \%)$, medium available nitrogen $(314.3 \mathrm{~kg} / \mathrm{ha})$, phosphorus $(19.8 \mathrm{~kg} / \mathrm{ha})$ and potassium (220.3 kg/ha). Sweet corn variety "Sugar 75" was sown on $21^{\text {st }}$ February, 2017 and harvested on $2^{\text {nd }}$ June, 2017.

The experiment was laid out in a randomized block design with three replications and twelve treatments viz. intercropping with mung bean, paddy straw mulching at $5 \mathrm{t} / \mathrm{ha}$, atrazine at $1000 \mathrm{~g} / \mathrm{ha}$, halosulfuron-methyl at $90 \mathrm{~g} / \mathrm{ha}$, tembotrione at $120 \mathrm{~g} / \mathrm{ha}$, atrazine at $1000 \mathrm{~g} / \mathrm{ha}$ with paddy straw mulching, atrazine at $1000 \mathrm{~g} / \mathrm{ha} f b$ halosulfuron-methyl at $90 \mathrm{~g} / \mathrm{ha}$, atrazine at $1000 \mathrm{~g} / \mathrm{ha} \mathrm{fb}$ tembotrione at $120 \mathrm{~g} / \mathrm{ha}$, atrazine at $1000 \mathrm{~g} / \mathrm{ha} \mathrm{fb}$ one hand weeding at $40 \mathrm{DAS}$, twice hand weeding at 20 and 40 DAS, weed free and weedy check.

Total weed biomass was recoded at 20, 40, 60, 90 DAS with $0.25 \mathrm{~m}^{2}$ quadrate and reported in $\mathrm{g} / \mathrm{m}^{2}$ by multiplying the values obtained from quadrate with four. For estimating soil dehydrogenase activity samples were taken at 30, 50 and 90 days after sowing by uprooting the crop plants and the root-adhering soil from rhizosphere was collected. $20 \mathrm{~g}$ dried processed soil sample (passed through $2 \mathrm{~mm}$ sieve) was mixed with $0.2 \mathrm{~g}$ of $\mathrm{CaCO} 3$ and placed into three tubes in equal parts. $1 \mathrm{ml}$ of $3 \%$ 2,3,5-triphenyl tetrazolium chloride and $2.5 \mathrm{ml}$ distilled water was added.

After vigorous shaking, the tubes were stoppered and incubated for $24 \mathrm{hrs}$. at a temperature of $36-37^{\circ} \mathrm{C}$. After incubation, 10 $\mathrm{ml}$ of methanol was added and mixed thoroughly. The sample was then filtered with a glass funnel plugged with cotton. After this, methanol was added into filtering funnel until the reddish colour disappeared completely from the cotton plug. The filtrate was collected and volume was made up to $100 \mathrm{ml}$ with methanol. The intensity of red colour of the filtrate was measured immediately in spectrophotometer at $485 \mathrm{~nm}$.

The concentration of dehydrogenase in the sample was obtained from the standard graph prepared using tri phenyl formazon (TPF) as standard, and expressed as $\mu \mathrm{g}$ of TPF released per $g$ soil on dry weight basis (Casida et al., 1964).

Total weed dry matter was transformed using square root transformation $(\sqrt{(x+1)})$ for the statistical analysis. All the data were analysed statistically by Fisher's least significant difference method at 5\% level of significance using IBM SPSS 24.0 software package developed by IBM Corp. (2016). 


\section{Results and Discussion}

The dominating weed flora in the experimental field was composed of Cynodon dactylon, Echinochloa colona among grasses, Celosia argentea, Alternanthera sessilis among broad-leaf weeds and Cyperus rotundus among sedges.

At 45 DAS, the highest total weed dry matter was observed in the weedy plots in all the stages followed by mung bean intercropped plots. All the weed control treatments significantly reduced total weed dry matter accumulation over the weedy check. At all the stages of crop growth, the lowest total weed dry matter accumulation was recorded from twice hand weeded plots among the weed control treatments followed by pre-emergence application of atrazine at $1000 \mathrm{~g} / \mathrm{ha}$ fb postemergence application of tembotrione at 120 $\mathrm{g} / \mathrm{ha}$.

These findings are in accordance with Swetha et al., (2015). Efficient control of grassy and non-grassy weeds in maize with postemergence application of tembotrione has been also reported by Singh et al., (2012) from Pantnagar. Dry matter accumulation in those treatments were closely followed by preemergence application of atrazine at $1000 \mathrm{~g} / \mathrm{ha}$ $\mathrm{fb}$ one hand weeding at 40 DAS.

At 45 DAS, the highest value of weed control efficiency was recorded from the twice hand weeded plots at 20 and 40 DAS which were at par with the pre-emergence application of atrazine at $1000 \mathrm{~g} / \mathrm{ha} \mathrm{fb}$ post-emergence application of tembotrione at $120 \mathrm{~g} / \mathrm{ha}$ among the weed control treatments.

Better performance of pre-emergence application of atrazine at $1000 \mathrm{~g} / \mathrm{ha}$ fb postemergence application of tembotrione at 120 $\mathrm{g} / \mathrm{ha}$, may be attributed to the fact that preemergence application of atrazine at $1000 \mathrm{~g} / \mathrm{ha}$ had good control over grassy and broad-leaf weeds at initial stages and the weeds were further taken care by the post-emergence application of tembotrione at $120 \mathrm{~g} / \mathrm{ha}$ at 20 DAS.

Low values of soil dehydrogenase activity at 30 DAS, indicating detrimental effect on soil micro flora, was recorded from pre-emergence application of atrazine at $1000 \mathrm{~g} / \mathrm{ha}$, preemergence application of atrazine at $1000 \mathrm{~g} / \mathrm{ha}$ $\mathrm{fb}$ tembotrione at $120 \mathrm{~g} / \mathrm{ha}$, pre-emergence application of atrazine at $1000 \mathrm{~g} / \mathrm{ha}$ with paddy straw mulching, pre-emergence application of atrazine at $1000 \mathrm{~g} / \mathrm{ha} \mathrm{fb}$ halosulfuron-methyl at $90 \mathrm{~g} / \mathrm{ha}$ and preemergence application of atrazine at $1000 \mathrm{~g} / \mathrm{ha}$ $\mathrm{fb}$ one hand weeding at 40 DAS.

Low values of soil dehydrogenase in all the atrazine $1000 \mathrm{~g} / \mathrm{ha}$ treated plots suggest the ill effects of the soil application of atrazine at $1000 \mathrm{~g} / \mathrm{ha}$ on soil microbial activity. The results were in accordance with Emurotu and Anyanwu (2016). The highest soil dehydrogenase activity was recorded in the paddy straw mulching at all the growth stages of the crop.

This may be due to the maintenance of soil temperature and better soil moisture due to the mulch and higher density of weeds may have caused a number of root secretions which may have improved the rhizosphere activity as indicated by the dehydrogenase activity. It may also be evidenced by the higher values of dehydrogenase activity in weedy check and mung-intercropped plots which had higher weed infestations and greater overall rhizosphere activity.

Foliar applied post-emergence herbicides had mild effects on soil dehydrogenase activity due to the fact that only a small amount of foliar herbicide reaches to the soil and they are also less toxic to soil micro flora. 


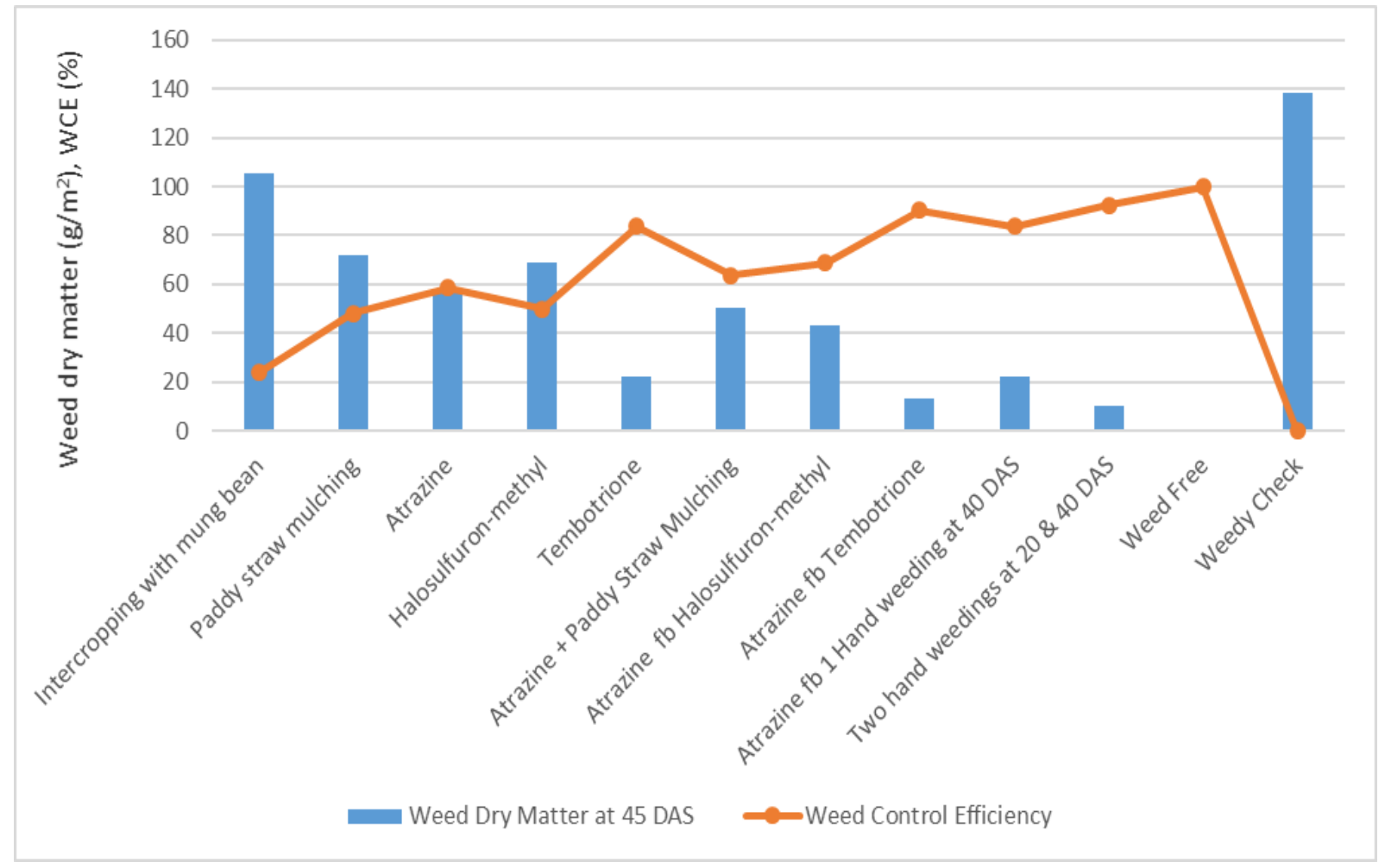

Fig. 1: Effect of weed management practices on weed dry matter accumulation at 45 DAS and weed

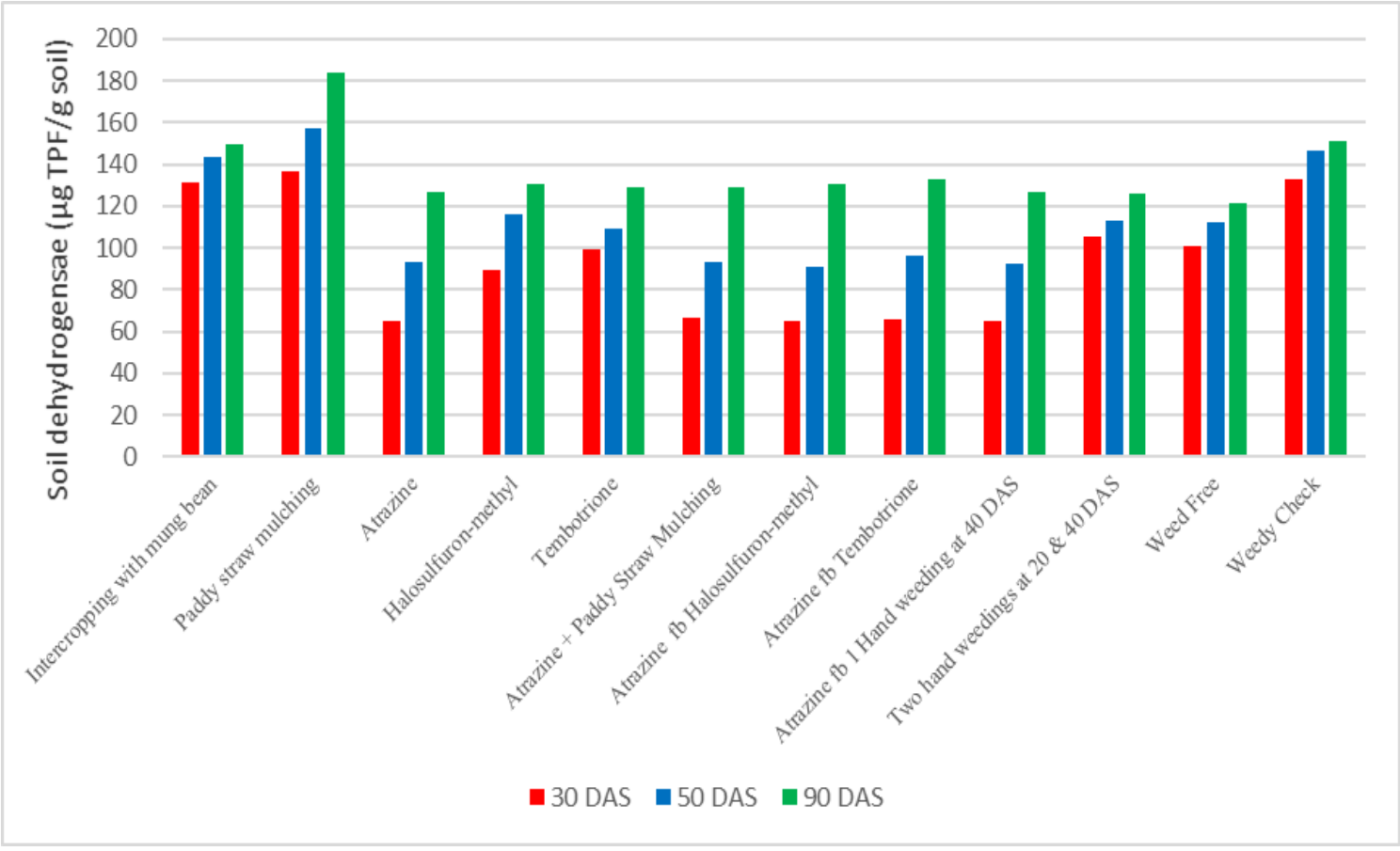

Fig. 2: Soil dehydrogenase activity as affected by different weed management treatments 
Table 1: Soil dehydrogenase activity as affected by different weed management treatments

\begin{tabular}{|c|c|c|c|c|}
\hline \multirow[t]{2}{*}{ Treatments } & \multirow{2}{*}{$\begin{array}{c}\text { Dose } \\
\text { (g a.i./ha) }\end{array}$} & \multicolumn{3}{|c|}{ Soil Dehydrogenase ( $\mu \mathrm{g}$ TPF/g soil) } \\
\hline & & 30 DAS & 50 DAS & 90 DAS \\
\hline Intercropping with mung bean & 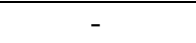 & 131.1 & 143.9 & 149.8 \\
\hline Paddy straw mulching & $5 \mathrm{t} / \mathrm{ha}$ & 136.3 & 157.1 & 184.3 \\
\hline Atrazine & 1000 & 65.3 & 93.1 & 127.0 \\
\hline Halosulfuron-methyl & 90 & 89.6 & 115.9 & 130.6 \\
\hline Tembotrione & 120 & 99.1 & 109.6 & 129.4 \\
\hline Atrazine + Paddy Straw Mulching & $\begin{array}{l}1000+ \\
5 \mathrm{t} / \mathrm{ha}\end{array}$ & 66.9 & 93.6 & 129.2 \\
\hline Atrazine $f b$ Halosulfuron-methyl & $1000 \mathrm{fb} 90$ & 65.2 & 91.3 & 130.6 \\
\hline Atrazine $f b$ Tembotrione & $1000 \mathrm{fb} 120$ & 66.1 & 96.1 & 132.7 \\
\hline Atrazine $f b 1$ Hand weeding at 40 & 1000 & & & \\
\hline DAS & & 65.2 & 92.3 & 126.7 \\
\hline Two hand weedings at $20 \& 40$ & - & & & \\
\hline DAS & & 105.1 & 113.2 & 126.3 \\
\hline Weed Free & - & 101.2 & 112.1 & 121.2 \\
\hline Weedy Check & - & 133.2 & 146.3 & 151.2 \\
\hline SEm \pm & - & 1.63 & 2.85 & 5.13 \\
\hline CD at 5\% & - & 4.83 & 8.51 & 15.17 \\
\hline
\end{tabular}

With the advancement of crop age, an increase in the dehydrogenase activity was recorded from all the treatments from the initial values. The initial downfall in the soil dehydrogenase activity has shown a trend of recovery in atrazine at $1000 \mathrm{~g} / \mathrm{ha}$ treated plots in later growth stages, may be due to the fact that microbes may have used the herbicide molecules as their carbon source and started to detoxify the toxicant and as a result of soil biological resilience. At harvest stage, there was a clear sign of recovery in the treatments which already had been recorded to have low dehydrogenase activity. Other postemergence treatments with tembotrione at 120 $\mathrm{g} / \mathrm{ha}$, halosulfuron-methyl at $90 \mathrm{~g} / \mathrm{ha}$ and cultural treatments were having a considerable amount of dehydrogenase throughout the crop growth period.

From the current study, it can be concluded that highest weed control efficiency and lowest weed dry matter accumulation was recorded in twice hand weeding at 20 and 40 DAS which was closely followed by preemergence application of atrazine $1000 \mathrm{~g} / \mathrm{ha}$ $\mathrm{fb}$ tembotrione $120 \mathrm{~g} / \mathrm{ha}$. But all the atrazine applied treatments resulted in adverse effects on soil microbial activity as indicated through soil dehydrogenase activity. Soil microbial population or activity doesn't directly influence the yield in the current season but they are important regulators of modifications in the rhizospheric environment and their number should be consistent enough in accordance as a mandatory component of soil biological health. The latter is duly acknowledged for the sustainability of the production system. So, consecutive application of atrazine $1000 \mathrm{~g} / \mathrm{ha}$ as soil application without proper allowance time for the soil micro flora to come back to its original state after the damage has been caused, should be strictly avoided from soil and environmental health point of view. Manual weeding and use of less toxic foliar applied herbicide can be used as options for effective weed control without deteriorating soil biological health.

\section{Acknowledgement}

The results are a part of master's thesis of Prithwiraj Dey submitted to G.B. Pant University of Agriculture \& Technology in June, 2018. The financial and technological 
helps from GBPUA\&T and ICAR are also duly acknowledged.

\section{References}

Casida, L.E., Klein, D.A., and Santoro, T. 1964. Soil dehydrogenase activity. Soil Science. 98(1):371-376.

Ehsas, J., Desai, L. J., Ahir, N.B. and Joshi, J.R. 2016. Effect of integrated weed management on growth, yield, yield attributes and weed parameters on summer maize (Zea mays L.) under South Gujarat condition. International Journal of Science, Environment. 5(4): 2050-2056.

Emurotu, M. and Anyanwu, C. 2016. Effect of atrazine and butachlor on soil microflora in agricultural farm in Anyigba, Nigeria. European Journal of Experimental Biology. 6(2): 16-20.

IBM Corp (2016). IBM SPSS Statistics for Windows, Version 24.0. Armonk, NY: IBM Corp.
Olabode, O. S. and Sangodele, A. O. 2015. Effect of weed control methods on the performance of sweet corn (Zea mays var. saccharata) in Ogbomoso, South West Nigeria. Journal of Global Biosciences. 4(1): 1145-1150.

Sharma, V. and Thakur, D.R. 1998. Integrated weed management in maize (Zea mays) under mid-hill condition of northwestern Himalayas. Indian Journal of Weed Science, 30: 158-162.

Singh, V. P., Guru, S. K., Kumar, A., Banga, A. and Tripathi, N. 2012. Bioefficacy of tembotrione against mixed weed complex in maize. Indian Journal of Weed Science. 44(1): 1-5.

Swetha, K., Madhavi, M., Pratibha, G. and Ramprakash, T. 2015. Short communication Weed management with new generation herbicides in maize. Indian Journal of Weed Science. 47(4): $432-433$.

\section{How to cite this article:}

Prithwiraj Dey, Tej Pratap, Sudershan Mishra, Sanjib Kumar Sahoo and Saipayan Ghosh. 2018. Different Weed Management Practices and Their Effect on Soil Micro Flora in Spring Season Sweet Corn (Zea mays L. saccharata) in Tarai Region of Uttarakhand, India. Int.J.Curr.Microbiol.App.Sci. 7(09): 2999-3004. doi: https://doi.org/10.20546/ijcmas.2018.709.373 